\title{
The population of ancient Rome
}

\author{
GLENN R. STOREY*
}

What was the population of imperial Rome? City blocks in Pompeii and Ostia are sufficiently well explored that a fair estimate of population density can now be arrived at. That peoples the city of ancient Rome with roughly 450,000 inhabitants, within the known population and density range of pre-industrial and modern urban centres.

\section{Introduction}

What was the population of ancient Rome? Many have believed there were as many as one million inhabitants - the figure in recent standard accounts (Brunt 1971: 376-88; Hopkins 1978: 96-8; Hodges \& Whitehouse 1983: 4852; Stambaugh 1988: 90; Bairoch 1989: 259; Robinson 1992: 8) and commensurate with the city's grandeur as capital of a great empire (FIGURE 1). But one million inhabitants in the 13.86 sq. $\mathrm{km}$ of the ancient city (Homo 1951: 98-9) is the astonishingly high density of 72,150 persons per sq. km, roughly equal to the density of sections of modern Hong Kong (Hong Kong Census and Statistics Department 1971). ${ }^{1}$

A population estimate can be made by combining lines of evidence (in a manner similar to recent research by, e.g., Blakely \& Mathews 1990; Crown 1991; Kardulias 1992), including the ethnohistoric record of Rome, the archaeological evidence of well-preserved Roman urban sites and the densities of pre-industrial and modern cities. A house-by-house population count for Pompeii and Ostia (including recon-

1 The area within the Aurelian Walls arguably did not constitute the full urban area of ancient Rome. However, it is unclear whether Rome had extensive 'suburbs' in the modern sense, or shanty towns. The question requires separate treatment; this analysis assumes that there were no large, high-density suburban residency zones outside the Aurelian Walls. That assumption (found in Homo 1951, repeating earlier arguments) does not mean the landscape was empty; far from it. But the settlement configuration just outside the walls, while having a higher than rural population density, was not an urban density, due to the tombs, market-gardens and luxurious villas of the wealthy. Purcell (1987a; 1987b) provides a useful discussion with references. structions of unexcavated areas) produces a population density statistic applicable to Rome and leads to a population estimate of the order of half a million.

\section{Background to demographic estimates for Rome}

Previous estimators of Rome's population have fallen into two opposite camps: the ones we can call the 'Great Rome' theorists argue for a million or more inhabitants, while 'Little Rome' theorists (so characterized by Carcopino 1940: 10 ) estimate at or below half a million; the history of demographic estimates reveals a pendulum swing between the extremes (G. Storey 1992: 17-62; Maier 1954). Many estimates in the favoured range of $750,000-1,000,000$ inhabitants start with the founder of the principate, Augustus, whose posthumous testament to the Roman people, the Res Gestae divi Augusti ('Achievements of the Divine Augustus') says (section 15):

Never did my largesse reach less than 250,000 people. In . . . [5 BC], I gave 240 sesterces to each one of 320,000 of the Roman people ... In ... [11 BC], I gave to Romans then on the grain dole 240 sesterces each. Their number stood at a little more than 200,000.

If these numbers are accurate, and if the 200,000 or 320,000 refer to a subset of the total population (probably male household heads), and if the remaining elements of the population - women and children, slaves, resident aliens, police forces, transients etc. - are added, then the population is at least 750,000 , possibly one million people or more (the earliest version of this argument is in Lipsius 1605: 113-20).

\footnotetext{
* Department of Anthropology, 114 Macbride Hall, University of Iowa, Iowa City IA 52242-1322, USA. E-mail: gstorey@blue.weeg.uiowa.edu
}

Received 20 December 1996, accepted 7 April 1997, revised 20 August 1997.

ANTIQUTTY 71 (1997): 966-78 


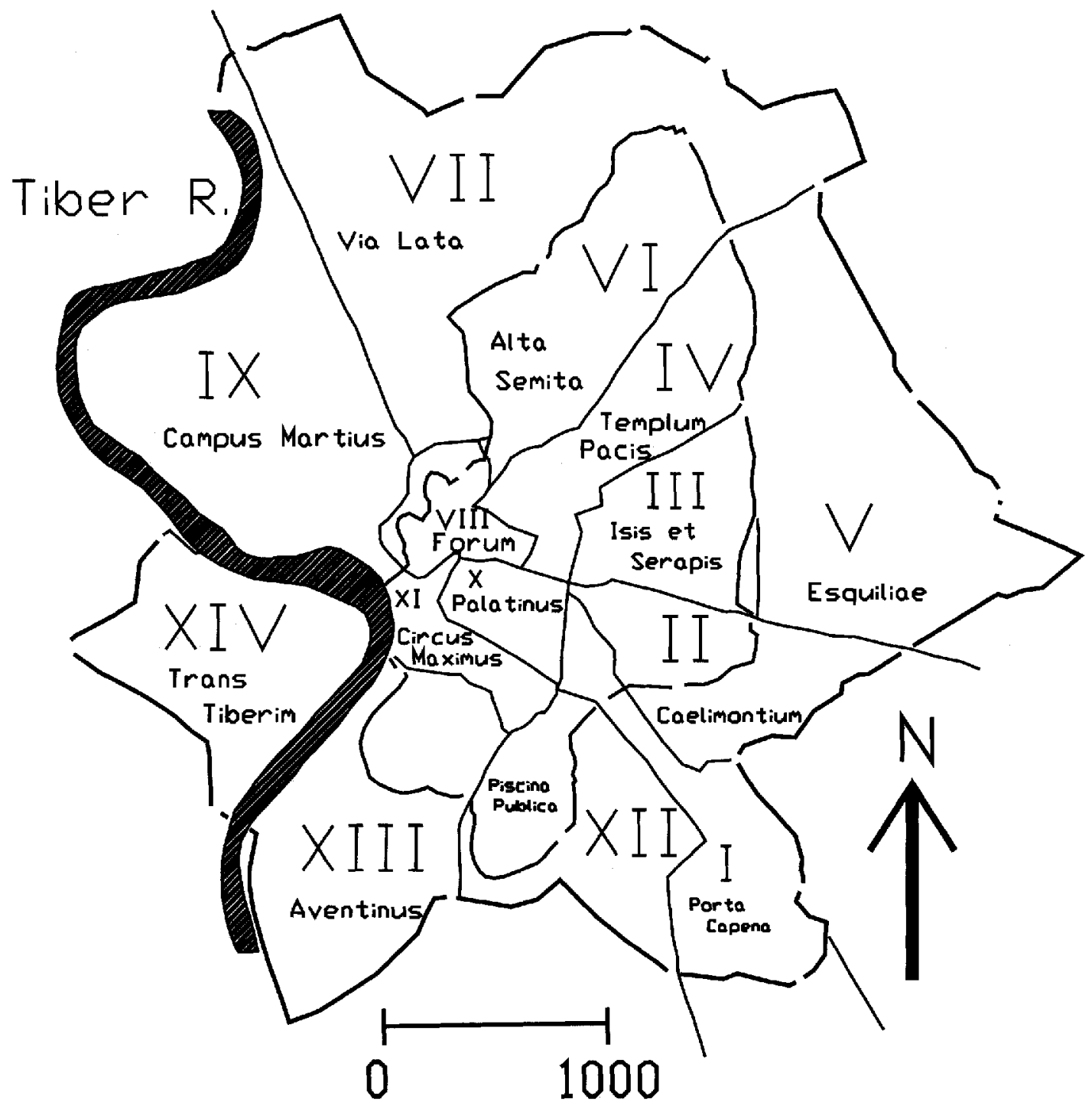

metres

FIGURE 1. Imperial Rome showing the boundaries, names, and numbers of the 14 regions established by Augustus in 7 BC. The inner Servian Wall is indicated by the thinner dark line (breaks show locations of gates in the walls). The outer Wall of Aurelian (thick dark line) enclosed $13.86 \mathrm{sq} . \mathrm{km}$. Although built in the 3rd century AD, the boundaries represented by the Aurelian Wall had been the customs boundaries since the mid 1st century $A D$, effectively defining the limits of the city. (After Stambaugh 1988: 83, figure 6.)

The citing of the figures 200,000-300,000 may have been chiefly political in intent, to glorify the accomplishments of Augustus (Finley 1985: 11, 32). The two relevant enumerations of the Roman census, 900,000 in $69 \mathrm{BC}$ and 4 million in $28 \mathrm{BC}$ are so disparate that some schol- ars believe that the Augustan census of $28 \mathrm{BC}$ must have included women and children, not just the usual male citizen family heads (Beloch 1968 [1886]: 370-78; Brunt 1971: 120; Nicolet 1991: 131); the counter-opinion in Frank 1924; Wiseman 1969; Lo Cascio 1994. 


\section{Ancient Rome and statistics}

'Census' is a Latin word, and the modern notion of a state counting the population is a direct legacy from the Roman system of counting its citizens. The complex Roman census process involved a sworn declaration of age, family and property, allowing the administration to record the city's human and property resources and to rank them (Nicolet 1991: 126). The procedure, originally confined to Romans in and near Rome, later expanded to subjects in the provinces for the purposes of taxation, as the Gospel according to Luke (2:1) says: 'And it came to pass in those days, that there went out a decree from Caesar Augustus, that all the world should be taxed.' This Judaean census, mistakenly identified by Luke as universal, was merely a provincial enumeration of taxable communities necessitated by an administrative re-organization initiating direct rule by the Romans. For the non-specialist observer of Rome, it demonstrates that Roman administration was an efficient record-keeping bureaucracy.

The Romans were not in the habit of recording, reporting and using statistical information for public policy-making, as governments do today (Finley 1985: 32), nor did ancient Rome, at the time of Christ, have a bureaucracy, collecting statistics for administrative purposes (Garnsey \& Saller 1987: 20-40). Under the Republic, the administrative tasks of governance were carried out by members of the slave household of each Roman statesman holding power. When Augustus founded the principate, he simply used his personal slave assistants as administrators (Weaver 1972). The elaborations and additions to this basic pattern evolved into the imperial bureaucracy, eventually an oppres. sive entity that bequeathed to English the negative connotations associated with the term 'Byzantine' (Carney 1971).

This view of how the imperial bureaucracy came into being - the 'primitivist' view (Nicolet 1991: 162-3) - posits a simple, ad hoc, undifferentiated administrative structure resembling a 'patchwork' of slowly evolving bodies of organization (Carney 1971: 29). But a considerable body of evidence suggests there was a long-standing Roman tradition of urban enumeration (Nicolet 1987), and that some sort of count of the inhabitants of the city of Rome was made at various times. Suetonius (Caesar 41.3) recounts:
He [Julius Caesar] carried out a recensus [partial census or review enumeration not requiring a sworn declaration], not according to custom nor in the usual place, but street-by-street, with the aid of the apartment house owners.

Suetonius (Augustus 40.2) also states that Augustus did likewise. These two occasions may not have been the first (Nicolet 1991: 129-30).

Urban record-keeping took other forms as well. At the beginning of the 3rd century AD, the Emperor Septimius Severus displayed the Forma Urbis Marmorea (Marble Plan of the City) - a map of ancient Rome, showing its streets, structures, and monuments (Carettoni et al. 1960; Rodriguez-Almeida 1981). The fragments of the Severan plan, about $10 \%$ that still exist, indicate that precise details of the urban configuration were known to administrators. Both Augustus and Vespasian had displayed similar plans (Palmer 1980: 227), which show houses and, apparently, even habitation units in many houses. The number of people in those units, which may have been matters of record, were not included on the maps. The precise administrative functions of the marble plans remain debatable; the kind of information-collecting reflected in these plans, and in the activities of the officials of Julius Caesar, Augustus and their successors, probably continued throughout imperial times.

There is no record of a city-wide census, whereas a census of all citizens throughout the empire, and partial censuses of entire subject populations, are known. A register of births and deaths in Rome and the provinces apparently was kept, which would be of enormous demographic value. Without those records themselves, our best expedient is to imitate, using modern methods, the process carried out to produce the Severan plan, taking it a step further by adding population counts for each unit. While this is impossible, at this point, for the city of Rome itself, other examples of the Roman archaeological record can make up for this deficiency.

\section{Methodology}

Pompeii, Ostia and AutoCAD

Pompeii, a city ruin in central southern Italy, is 75\% excavated (Jashemski 1979:6). This site, once a resort and market centre $200 \mathrm{~km}$ south of Rome, offers an excellent opportunity for understanding Roman urban public and domestic structures because of its preservation by the eruption of $\mathrm{Mt}$ Vesuvius in AD 79 (De Vos \& De Vos 1982; 
Richardson 1988; Jongman 1988; Laurence 1994; Wallace-Hadrill 1994). The layout of the city has been extensively studied and documented, even to identifying the function (and even ancient ownership) of a large proportion of the existing remains, although the methods of identification are not completely reliable (Della Corte 1965; Eschebach 1970; 1981; Castrén 1975: 21-37; Jongman 1988; Wallace-Hadrill 1991: 219; Van der Poel et al. 1983). Pompeii is ideal for generating an accurate demographic estimate based on a hypothetical house-by-house inhabitant count.

Closer to Rome is the city of Ostia, once Rome's port at the mouth of the Tiber River, a rich city about 50\% excavated (Packer 1971; Meiggs 1973; Calza 1953; Pavolini 1988). Ostia differed from Pompeii in urban functions; its livelihood was derived from commerce, and it did not depend extensively on its own hinterland for subsistence support. The evidence of Pompeii and Ostia, taken together, represents the best avenue to understanding the configuration and urban characteristics of ancient Rome (Packer 1971: 1; Ward-Perkins 1974: 36). ${ }^{2}$

As neither city has been completely excavated, neither provides a complete house count for a census. To correct for this, computer-generated archaeological maps (FIGURES 2 \& 3), including suppositions about unexcavated areas, were made for both sites by digitizing existing archaeological maps (Ostia: Gismondi in Calza 1953, with later updates from Pavolini 1988; Pompeii: Eschebach 1981) and using the AutoCAD architectural drawing software package (versions 10 and 12 ). ${ }^{3}$

2 Rome, Ostia and Pompeii are not 'typical' Roman cities, but the degree of the 'atypical' found in Pompeii and Ostia occurred also in Rome. Pompeii's houses, possibly bigger than in a non-resort town, would also be found in Rome because the governing élites had their largest residences there. Ostia's commercial functions also characterized the capital as well as the high frequency of apartment residency.

3 As pointed out by Wallace-Hadrill (1994: 71), the structure function identifications of Van der Poel et al. (1983) are probably more reliable than those of Eschebach (1970; 1981) utilized here. However, the most frequent emendation required by Van der Poel et al. (1983) would be changing Eschebach's commercial/industrial function identifications back into ordinary private domus. The occupancy differentials between those two types of structure uses would not significantly alter the results, or, if they did, they would serve only to increase moderately the number of occupants because Roman 'cottage' industries would have had worker contingents similar in size to the average slave contingent of a private domus. So, Eschebach's identifications, though questionable in a number of cases, still yield reasonable results.

\section{Features of the AutoCAD maps}

The configurations of the maps maximize the population estimates because the goal is to identify the largest possible population size. The maps were constructed as separate layers of functionally distinct buildings: public structures, domestic structures, shops, apartments, taverns, production loci, and for estimated as opposed to known configurations.

In estimating for the unexcavated areas, the unexcavated areas of both sites were taken to be chiefly residential. In Roman cities, structures of differing functions commonly appeared in the same district; there was no overt zoning in the modern sense (Paoli 1963 [1940]: 5-32; Laurence 1995: 64-5). There was the well-known tendency of craftsmen plying the same trade to congregate in the same neighbourhood (Paoli 1963 [1940]: 33-5), and a tendency for warehousing to concentrate in the same places. But the mixing meant that shops, workshops, living quarters, taverns, etc. were located in most districts of every city.

Public and non-residential structures have accordingly been 'rebuilt' into the fabric of the unexcavated areas, but no major concentrations of non-residential architecture have been added. Nothing similar to a large public Forum complex was placed in either city's unexcavated regions; with all the work that has been done at both sites, it is unlikely that major complexes of public structures remain to be discovered.

The estimated configurations were patterned after the main residential zones seen in the excavated parts of each city, with nothing inappropriately placed where it could not believably have actually stood.

\section{The basis of the population estimates}

Two types of residences characterize the fundamental patterns of Roman domestic life: the domus, a private town-house or mansion, and the apartments, either individual units or arranged in blocks or buildings, known as insulae (literally 'islands'). The bulk of the residential population inhabited these two types of buildings. The pattern of residence seems to have been basically one family per unit (Paoli 1963 [1940]: 56; Meiggs 1973: 235-62), but how many people constituted the average Roman family?

Bradley (1991) and Wallace-Hadrill (1991) have argued that the concepts of 'nuclear' and 'extended' families for Roman society inad- 


\section{$A^{N}$ \\ $\widetilde{0100}$ \\ metres}

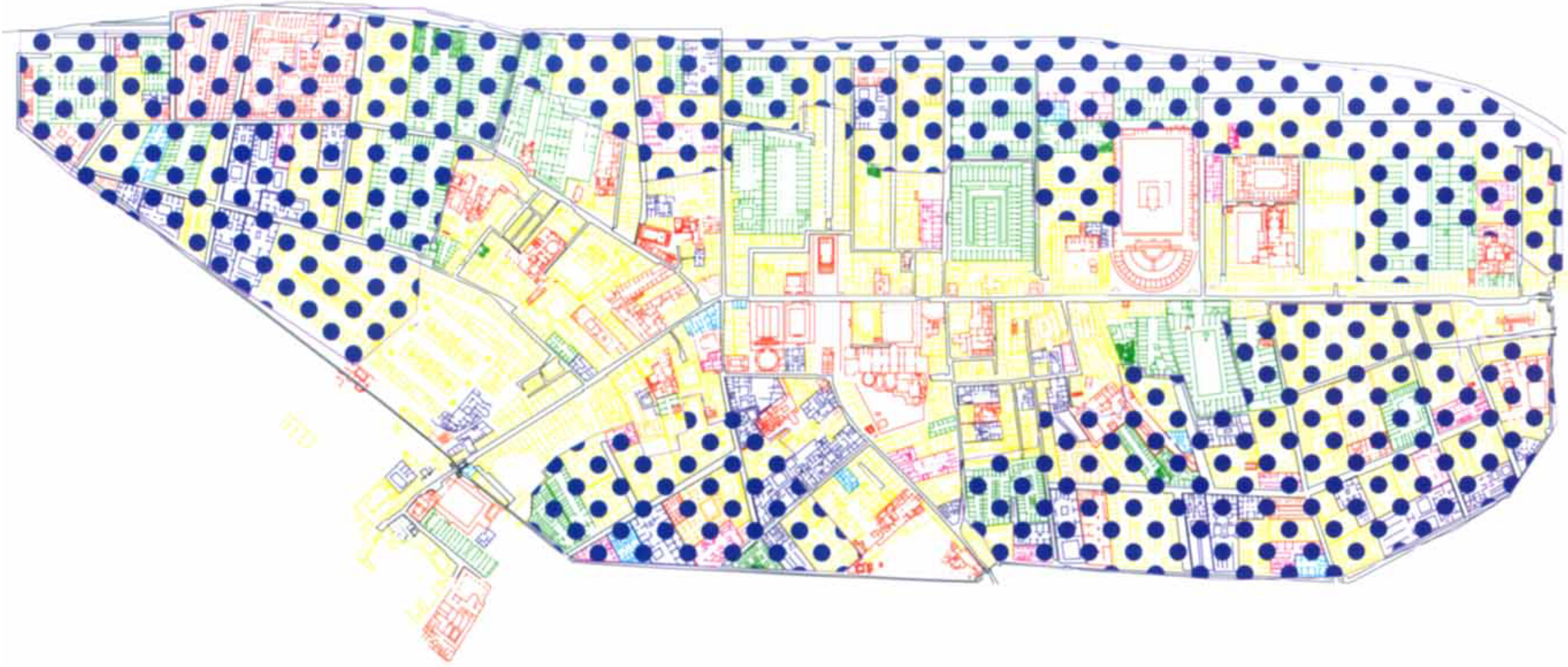

FIGURE 2. AutoCAD map of Pompeii, as it may have looked on 24 August AD 79. Colour code: black=streets, walls and water distribution points; blue=private houses (domus); green=gardens; red=public facilities; turquoise=entertainment facilities; magenta=commercial/industrial facilities; yellow=apartment units (insulae); orange=facilities for collegia (guilds); blue dots indicate conjectured configurations for unexcavated zones. 


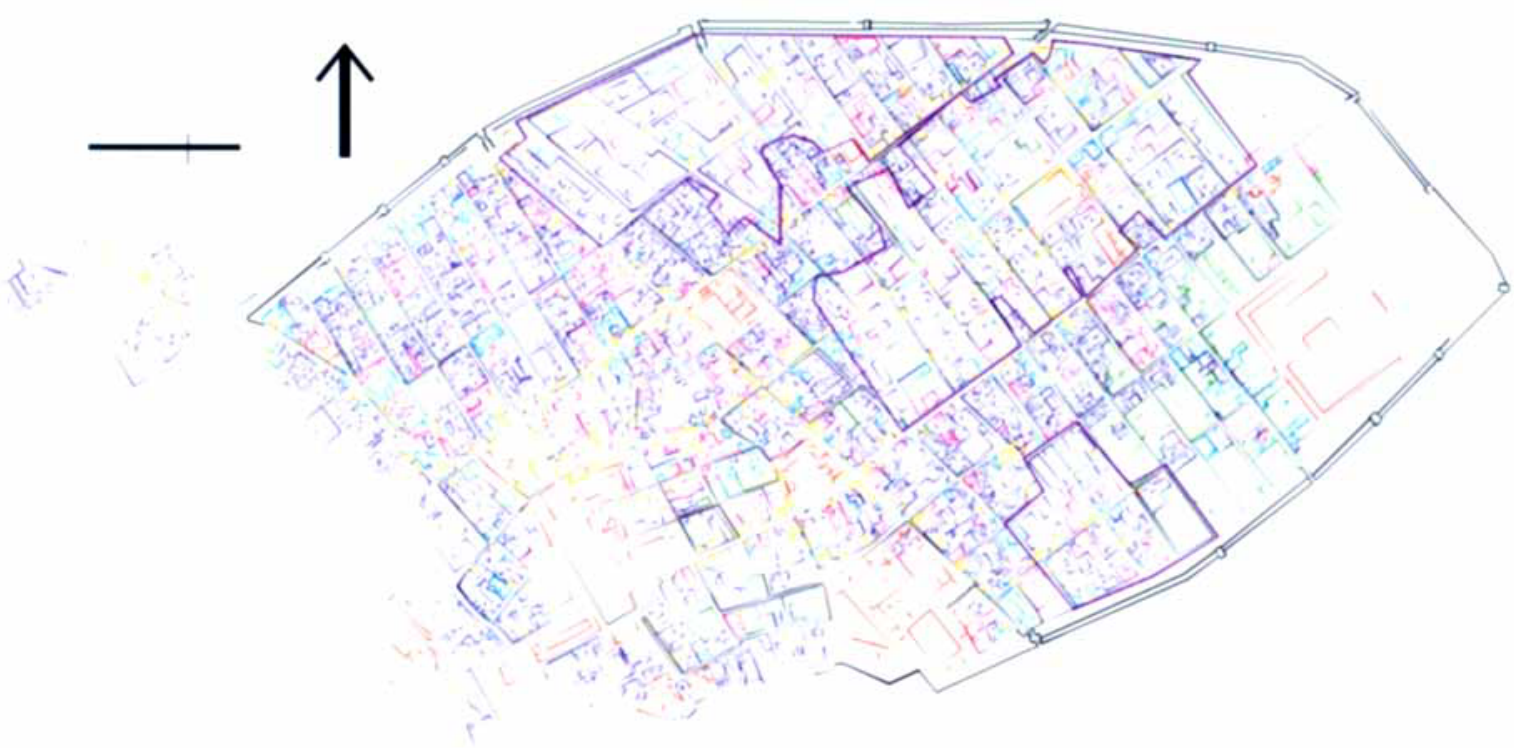

FIGURE 3. AutoCAD map of Ostia, showing the existing and reconstructed remains of the city dating from the 2 nd to 4 th centuries AD. Colour code as for FIGURE 2, except that black includes docks conjectured along the river front at the top of the map and green=warehouse facilities.

equately describe an extremely complex institution, with high incidence of divorce and remarriage. Their argument, though correct, does not upset the factual residential character of the Roman family unit, a core nuclear family with conjugal couple and dependent children. The Roman family, as a co-residential unit, was of the nuclear, not the extended, variety (Saller \& Shaw 1984; Shaw 1984; Saller 1984; Rawson 1986: 8-15; 1991a: 1-5; Parkin 1994). Not all progeny of all past unions of the two remarried adults were living together at any one time, in the same house or apartment.

This conjugal nuclear family provides a reasonably well-defined basic unit. It is generally agreed that the pre-industrial nuclear family was small - averaging between 3 and 5 or 6 individuals at any one moment (Russell 1958; 53; Haviland 1972; Parkin 1992: 91-133; Evans 1993). Prior to the 'demographic transition', when health and medical practice began to depress the level of mortality below the level of fertility and trigger explosive population increase, high natural fertility was offset by high infant mortality (Weiss 1973: 42-51, 55-6, 77-8), a factor particularly characteristic of pre-industrial urban centres due to their general problems of sanitation (Teotihuacan: R. Storey 1992; Europe in general: de Vries 1984; London: Finlay 1981; Rome: Brunt 1971: 133-6, 385-8; Scobie 1986). 
This basic size for Roman family units can be adjusted both up and down. The small apartment units, it seems clear, characteristically held either a single individual or a partial family. The Roman written record describes the smallest apartment units, with indications strongly pointing to common habitation by single men, a pair of single men, a single mother and her children or small nuclear families. ${ }^{4}$ The anthropologically derived range of 3 to 5 or 6 persons is reasonable for these families of lower socioeconomic status since they did not possess sufficient wealth to own their own houses (McKay 1988: 1373-4, 1378-9).

The inhabitants of private town-houses or mansions had greater wealth (Wallace-Hadrill 1991; 1994). Presumably, the nuclear families inhabiting these houses were the same size as the 'normal' pre-industrial nuclear family characterizing the shops and apartments, again 3 to 5 or 6 individuals. These households contained retainers, poorer relations and slaves.

The number of slaves in Roman antiquity is a vexing question. The common view continues to be that the number of slaves in Roman culture was large - of the order of one-third to $40 \%$ of the population (Brunt 1971: 124, 7023; Bradley 1994: 29-30). The commonly cited 'one-third' comes from one source, the Greek physician of the imperial period, Galen of Pergamon (c. 130-200 AD) in a work called 'On the suffering of the soul' (Kuhn 5.49). Galen suggested that the population of the Greek city of Pergamon in western Turkey was about 120,000: 40,000 citizen males, 40,000 women and children and 40,000 slaves (one slave for every two free persons). In the numerous citations of this source, it has rarely been pointed out that Galen's language in the passage is highly

4 The poetry of Martial (Marcus Valerius Martialis c. AD 38-104) and Juvenal (Decimus Junius Juvenalis $C$. AD 60130 ) is particularly suggestive on the question of single men: see for example, Martial Epigrams 1.86; 1.117.6-7; $2.53 ; 3.30 .3-4 ; 8.14 .5-6 ; 8.20-22 ; 11.32 ; 11.56 .3-8 ; 12.18 .1-$ 6; Juvenal Satires 3.197-202. Suetonius (Gaius Suetonius Tranquillus $c$. AD 70-140) also noted that poor single men lived alone in small upper-floor apartments (On Grammarians and rhetoricians 9). Regarding single men living together Diodorus Siculus (c. 80?-21? BC World History 31.18.2) reported that the impoverished Egyptian monarch Ptolemy XII lived cheaply by sharing an upper-floor apartment in Rome with a Greek scholar, due to the high rents. Regarding a small household, Martial describes a rent-dodging family unit consisting of a man, his wife, mother and sister (Epigrams 12.32.1-25) conditional. K.J. Beloch doubted its utility (an 1897 observation quoted in Lo Cascio 1994: 25, n. 12, 27), as have Warden \& Bagnall (1988: $220, n$. 2) more recently. Galen's source for these figures is unknown, and it is improbable that the number of males, females and children would have been equal.

Other sources give a different view of the number of slaves, and imply that slave holding on the part of most individuals in Roman society was moderate - maybe two or three per family (Horace Satires 1.3.11-12; Dionysius of Halicarnassus World History 31.18.2). But the scattered references in the historic record that report an extreme situation (200 slaves, Horace Satires 1.6.116; 4116 slaves, Pliny the Elder Natural History $33.135 ; 400$ slaves, Tacitus Annals 14.4) have been accorded greater weight. 'One of the problems about the literary evidence', Wiedemann remarks (1981: 100), 'is that what was thought worth noting down was almost always what was exceptional'. There is no doubt that the imperial household was the largest body of slaves in the ancient world, but no evidence to agree with Carcopino (1940: 70) that they numbered some 20,000 . This might be true were every slave on every imperial estate in the Empire to be counted; it is doubtful for the palace and city contingent stationed in Rome. For the population of imperial slaves resident in Rome, a few hundred or a thousand or two at most seems more realistic.

Carandini's recent excavations of élite household buildings in the very heart of the Roman Forum have demonstrated that the number of slaves was small (1988: 359-87). Even if élites resident in Roman cities owned hundreds of slaves, it is equally true that not all of those slaves would have been domiciled there; the Roman élite owned multiple houses, and each would have had its resident slaves. Evidence from Roman Egypt suggests that common slave holdings for wealthy families were from 6 to 18 , with one exceptional case of up to 70 (Wiedemann 1981: 101). Thus, the number of slaves in most élite households was moderate (see Westermann 1955: 86-9, especially 88). Counting slaves and any resident retainers or poor relations (not always present), the members of the household outside the nuclear family would likely have been 10-12. So, adding the basic 'master' nuclear family size ( 3 to 5 or 6 ) to the household slave and others contin- 
region
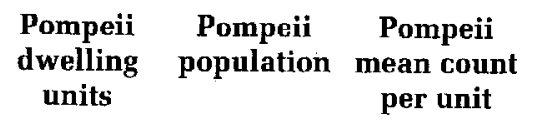

Ostia
dwelling
units

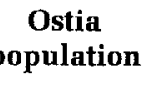

outside Herculaneum

gate

one

two

three

four

five

six

seven

eight

nine

total

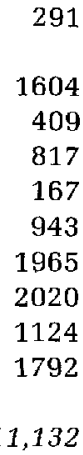

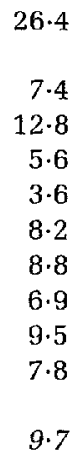

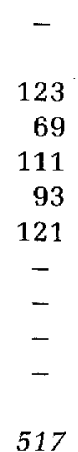

517
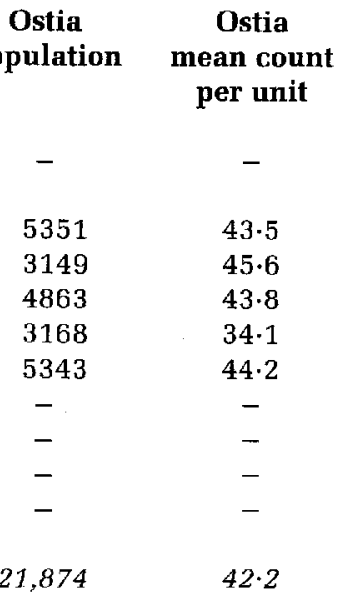

$43 \cdot 5$

$45 \cdot 6$

$43 \cdot 8$

$34 \cdot 1$

$44 \cdot 2$

-

$-$

$-$

$42 \cdot 2$

TABLE 1. Population counts for Pompeii and Ostia. The 'region' designations are modern conventions (nine defined for Pompeii; five for Ostia).

gent size (10-12) yields a total house occupancy of between 13 and 17 .

\section{Assignment of counts procedures}

With these assumptions, the simulation was carried forward: for both cities, each residential unit (real or fictive) was assigned an occupancy count, using the $3-5$ or 6 range for apartment dwellings, the 13-17 range for private houses. The assignment of an actual number was guided chiefly by the size of the unit: in most cases, a small unit was assigned a figure towards the lower end of the appropriate range, a larger unit towards the upper end.

That rule was deliberately and randomly violated to reflect more faithfully the habitational realities of urban life, as rightly emphasized by Wallace-Hadrill (1991: 202, 213, 214, 2257). Not all large units hold more people, or small ones fewer. In modern US society, a well-off widow occupies a large mansion, while a twobedroom apartment houses eight people in the inner city. Roman examples would be: an aging élite couple with a handful of slaves occupying one of the larger town-houses in the backstreets of Pompeii; two families of commoners recently evicted from their land in southern Etruria who try to make a living selling ceramic vessels in a small shop-front in Ostia, squeezed into the small mezzanine apartment upstairs with two slaves sleeping on the shop floor; or, the son of a low-ranking senator who occupies a spacious three-room apartment on the second floor of an apartment house with three slaves.
About $20 \%$ to $25 \%$ of the total sample was varied in this way. To assure that the procedure was applied consistently, no totalling was done until all assignments were complete for both sites.

\section{Results}

TABLE 1 gives the totals for both sites: Pompeii has a population of 11,132 inhabitants, at a density of 16,615 persons per sq. km; Ostia has 21,874 inhabitants, at a density of 31,700 persons per sq. $\mathrm{km}$.

Previous estimates for Pompeii (summarized in Jashemski 1979: $343 \mathrm{n}$. 56) range from 6400 (Russell 1977) to 30,000 (Cary \& Scullard 1975), but the range favoured today - between 8000 and 12,000 (Jongman 1988: 110-12; WallaceHadrill 1991: 199-200) - finds strong support from the simulation. It also matches recent work by Wallace-Hadrill $(1991 ; 1994)$ who subjected a sample of houses from Pompeii (and Herculaneum) to scrutiny as to their sizes, layouts and probable parameters of occupancy. As in this current study, Wallace-Hadrill worked from the 'bottom up', looking 'in detail at the evidence of the houses themselves [to] see what they imply about the density and distribution of population within the city' (1991: 201). He assumed a population of around 10,000 (1991: 203). The maximum number of dwelling units thought to exist in the entire city was 1500 , close to the 1427 of this study. His average household unit size was $7 \cdot 7$ to $8 \cdot 3$, although his method shied away from simple average 
year

population

population density

(persons per sq. km)

$\begin{array}{lll}1881 & 272,012 & 18,675 \\ 1901 & 424,860 & 26,289 \\ 1911 & 409,263 & 25,324 \\ 1921 & 471,857 & 29,127 \\ 1931 & 460,196 & 29,347 \\ 1951 & 444,009 & 28,315\end{array}$

Source: Comune di Roma Ufficio di Statistica e Censimento 1960 Tavole 17, 65; Tavole 19, 68; Tavole 21, 70; Tavole 23, 73; Tavole 25, 76; Tavole 42, 233.

TABLE 2. Modern city of Rome population 18811951.

statistics. The result in this study (TABLE 1) is also not very different -9.6 persons per unit.

Strocka (1984: 49-50) concluded that the house in Region 6, Block 15, Doors 7 and 8 at
Pompeii contained a private suite for 6-10 family members and slave quarters for $3-5$, in a domus that probably housed 12-20 people, when houseowners, tenants and slaves are included. Wallace-Hadrill noted that the figures could easily be reversed: 6-10 slaves, a family of 3-5 for the private suite (1991:222). These independent results, strongly supportive of the method and result in this current study, bring an accurate picture of the city's population within sight: the scale of 6000 for Pompeii is not correct, nor is the scale of 20,$000 ; 11,000$ is the better figure. With about $75 \%$ of Pompeii fully excavated, the degree of completeness in the data helps investigators, working from similar methodologies and assumptions, to arrive at a consensus.

For Ostia, previous estimates (briefly discussed in Meiggs 1973: 532-5) range from 20,000 (Nibby 1829: 61) to 100,000 (Calza 1926: 16). Packer (1971:

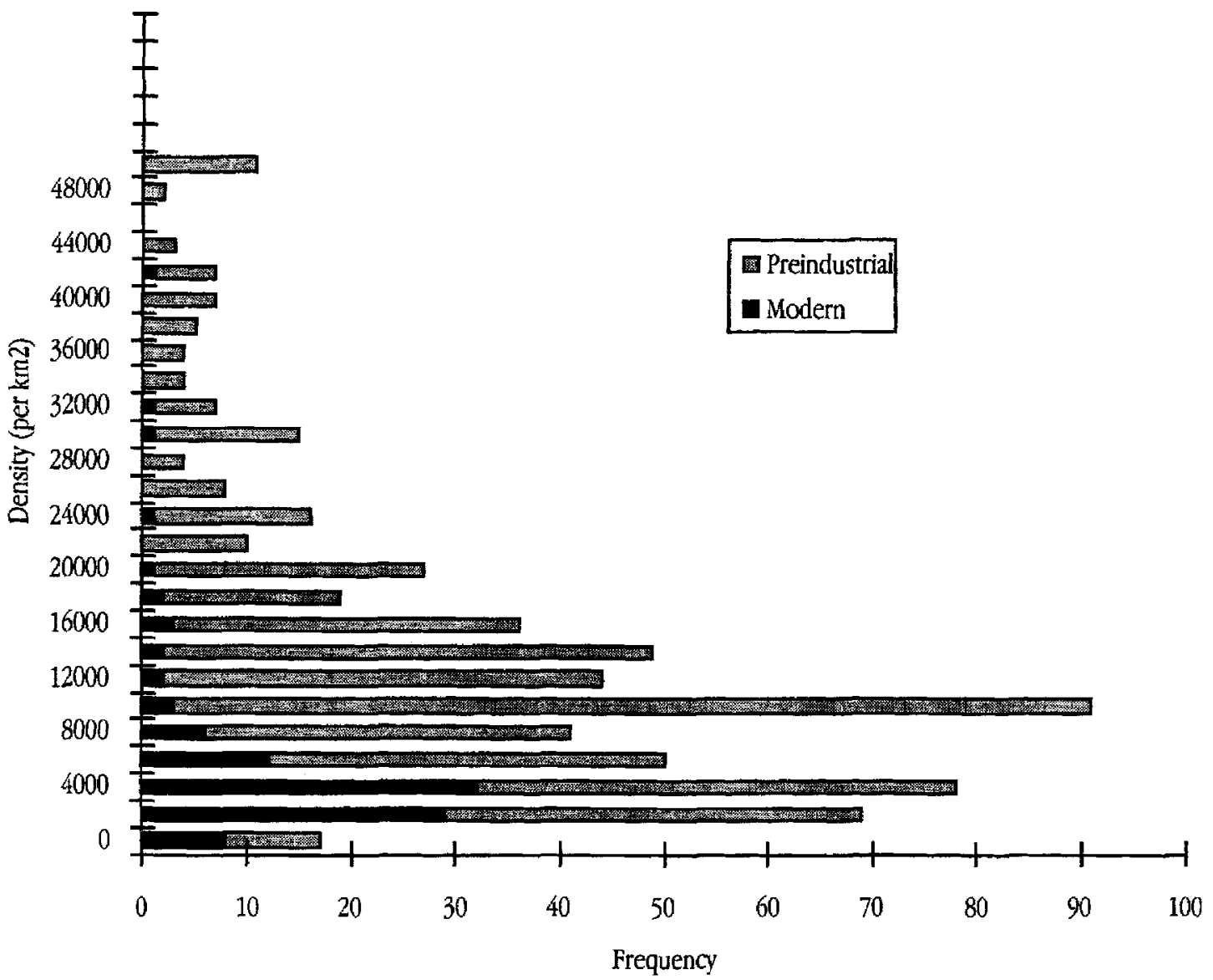

FIGURE 4. Histogram of urban population densities, from a sample of 531 cities: 425 pre-industrial cities (up to 1930), and 106 modern cities (1980 and 1985 United Nations statistics). 
70), with careful analysis of the residential units and a family size of 4 (from Russell's 1958 study), concluded that Ostia was inhabited by no more than 27,000 people. The current study at 22,000 substantiates Packer's conclusions, and Nibby's 19th-century estimate seems remarkably astute. The high figures of $35,000,50,000$ and the unlikely 100,000 are incorrect. ${ }^{5}$

These two population densities based on Roman archaeological data from Italy can be applied to ancient Rome. The average of the two densities - one nearly twice the other - is 24,158 persons per sq. $\mathrm{km}$. Applied to the known area of the ancient city $-13.86 \mathrm{sq} . \mathrm{km}$ enclosed by the Walls of Aurelian - this makes the ancient population of the city about 335,000 . So, applying the higher figure from Ostia alone, the city of warehouses and apartment houses, to Rome, also a city of warehouses and apartments, at 31,700 persons per sq. $\mathrm{km}$, the ancient population of Rome was 440,000 .

The recent population history of Rome in the area roughly equivalent to that of the ancient city is relevant. The period 1881-1951 (TABLE 2 based on Comune di Roma Ufficio di Statistica e Censimento 1960) saw a growth in the population of the city that had only occurred previously in antiquity - to a maximum about that estimated for antiquity: some 450,000 , with a density of close to 30,000 persons per sq. $\mathrm{km}$ at its most crowded. Even conceding the many differences between antiquity and modern times, these recent data should give pause to the claim that ancient Rome had one million inhabitants.

\section{Population density in a cross-cultural perspective}

Is the half-million result reasonable in other respects? Substantiating evidence can be drawn from systematic analysis of urban population densities derived from adequate census data and from less-adequate observer-traveller estimates. A sample is used of 531 cities, 425 preindustrial cities, 106 modern. Their densities cluster well below 20,000 persons per sq. km (FIGURE 4). In the entire combined sample, all but 14 of the 531 cities, or $97.6 \%$, had densities below 45,000 persons per sq. $\mathrm{km}$; the mean

5 Janet DeLaine (pers. comm, 1995) reports one of her students, Andrew Pearson, recalculating the population of Ostia, arrived at a figure of 22,000 . is 14,542 , with the distribution heavily skewed to the lower end; the median is $10,935 .^{6}$

The modern city sample (the 106 largest urban centres according to the United Nations) shows a similar profile: mean density 5991 persons per sq. km; median 3790 per sq. km; maximum 42,571 (Manila in the 1980s). No modern city possesses an overall population density remotely near that for an ancient Rome of one million people. Although modern cities might seem able to support very high densities with advanced architectural and transport technology, in fact, they sprawl over very large territories in comparison to pre-industrial cities; the mean area of the pre-industrial sample is $6.63 \mathrm{sq} . \mathrm{km}$, of the modern 807.

The mean density of the pre-industrial sample of 425 is 16,661 persons per sq. km (median 12,897): the pre-industrial cities were more crowded and compact than modern ones. These data are based on various estimates reported in a variety of sources at a variety of periods; few accurate censuses of urban populations exist before that for London of 1801 (Abstract . . . 1801), based on a count from parish registers.

Chandler \& Fox's study of urban growth (1974) compiles many different estimates and with supplementary sources - including New World archaeological estimates independently arrived at - indicate a normal urban density range of $10,000-20,000$ persons per sq. km (Casselberry 1974; Haviland 1972; Blanton 1981; Millon 1981; Calnek 1976; Healan 1977; Sanders et al. 1979; Culbert \& Rice 1990; Webster \& Freter 1990).

If the pre-industrial data do represent a reasonable picture of population density, pre-industrial cities were more dense than their modern counterparts; for the 205 pre-industrial European cities, the average is only 18,042 persons per sq. km. Only four cities exceeded

6 The data are from the following sources: Census of England and Wales 1881; Ministero di Agricoltura, Industria e Commercio, Direzione della Statistica 1883; Ministère du Commerce Service de la Statistique Générale 1883; Lot 1945-1950; Frankfort 1950; Russell 1958; Adams \& Nissen 1972; Chandler \& Fox 1974; Calnek 1976; Schinz 1989 United Nations Population Fund 1988. The Chandler \& Fox volume is the main source for the pre-industrial data, and Chandler (1987) has up-dated the volume. A preliminary analysis of the more recent data, a sample of $273 \mathrm{en}$ tries, shows a 98.9 cumulative percent below 45,000 person per sq. $\mathrm{km}$ and a mean density of 13,789 persons per sq. $\mathrm{km}$, lower than the results reported below. 
50,000 persons per sq. $\mathrm{km}$, and none equalled or exceeded 54,112 persons per sq. $\mathrm{km}$, the density equivalent to an ancient Rome of 750,000 inhabitants.

For the 82 pre-industrial cities existing during the Roman period, the mean density falls to 13,607 persons per sq. $\mathrm{km}$; within a range from 4000 to $37,750,94 \%$ of the cities have a density below 22,000. Not one Roman, European or other pre-industrial city equals the population density for an imperial Rome of one million inhabitants — or even of 750,000 inhabitants.

\section{Discussion}

The density figure for Pompeii is roughly average for a pre-industrial urban density sample, that for Ostia is comparatively high, and well within the range of possibilities. Stambaugh, realizing that an ancient Rome of one million persons equals a population density in the 70,000s per sq. $\mathrm{km}$ found evidence to support that figure (1988: 90$)$ :

If we assume a population of about a million, we must conclude that Rome in the early principate was one of the most densely populated cities the world has ever known - as crowded, probably, as modern Bombay or Calcutta.

\section{References}

Abstract of the answers and returns made pursuant to an Act passed in the Fifty-First Yoar of Llis Majesty King George III intitled 'An Act for taking an Account of the Population of Great Britain and the Increase or Diminution thereof enumeration Part 1, Lngland and Wales. 1801. London: Great Britain Gonoral Rogister Office.

AJAMS, R. McC. \& H. Nissin. 1972. The Uruk countryside. Chicalgo (II): Aldine.

BAIROCI, P. 1989. Urbanization and the economy in preindustrial societies: the findings of two decades of research, Journal of European Economic History 18: 239-90.

B]1,och, K.J. 1968 [1886]. Die Bovölkerung der GriechischenRömischen Welt. Rome: L'Erma di Bretschneider.

BLAKELY, R.L. \& D.S. MATHEWS. 1990. Bioarchaeological evidence for a Spanish-Native American conflict in the 16thcentury southeast, American Antiquity 55(4): 718-44.

BLANTON, R.E. 1981. The rise of citios, in Sabloff (ed.): 392-402

BRADI. K. K. 1991. Discovering the Roman family: studies in Roman social history. New York (NY): Oxford University Press.

1994. Slavery and society at Rome. New York (NY): Cambridge University Press.

BRUNT, P.A. 1971. Italian manpower: 225 BC to AD 14. New York (NY): Oxford University Press.

CALNIK, E.L. 1976. The internal structure of Tenochtitlan, in E.R. Wolf (od.), The Valley of Mexico: studies in pre-Hispanic ecology and society: 287-302. Albuquerque (NM): University of New Mexico Press.

Calza, G. 1926. Ostia. Rome: La Libreria dello Stato.

(Ed.). 1953. Scavi di Ostia: topografia generale. Rome: La Libreria dello Stato.
But Bombay's 1980 density was 18,796 persons per sq. km; Calcutta's was 31,779 (United Nations Population Fund 1988) - very much as calculated for Pompeii and for Ostia, respectively! Those densities, when applied to the area of ancient Rome, result in a population well under half a million. Stambaugh used a 'spot density' from United Nations (1980) statistics. Spot densities are extremely high population densities found in cities all over the world - but in exclusively small areas of only a few hectares to one or two sq. kms. Only by applying a modern spot density statistic to the entire urban area of ancient Rome can the one million population figure be reached. Beyond the city of Rome itself lay a hinterland territory of roughly $2500 \mathrm{sq}$. $\mathrm{km}$. If a population of one million is to be supposed, it would be across that larger region, comparable to that estimated for the entire population of the Basin of Mexico during the Late Horizon Aztec period on the eve of the Spanish conquest (Sanders et al. 1979).

Acknowledgements. Special thanks to Susan Evans and Winfield Swanson for their assistance, the University of Iowa Office of Research for generous support for graphics reproduction, and my wife, Andrea Storey. All shortcomings of this paper are the author's alone.

CARANDINI, A. 1988. Schiavi in Italia: gli strumenti pensanti dei Romani fra tarda Repubblica e medio impero. Romo La Nuova Italia Scientifica.

CArcopino, J. 1940. Daily life in ancient Rome: the people and city at the height of the Empire. New Haven (CT'): Yale University Press.

Carettoni, G., A.M. Colini, L. Cozza \& G. GatTi, 1960, La pianta marmorea di Roma antica: forma urbis Romac. Rome: M. Danesi.

CARNLY, T.F. 1971. Bureaucracy in traditional societies: RomanoByzantine bureaucracies viewed from within. Lawrence (KS): Coronado.

CAKY, M. \& H.H. SculLaRd, 1975. A history of Rome down to the reign of Constantine. 3rd edition. New York (NY): St Martin's.

CASSEI,BURY, S.E. 1974. Further refinement of formulae for determining population from floor area, World Archaeology 6(1): 117-22.

CASTRÉN, P. 1975. Ordo populusque pompeianus: polity and society in Roman Pompeii. Rome: Bardi Editore. Acta Instituti Romani Finlandiae 8.

Census of England and Wales 1881 area, houses and population 1. 1883. London: Eyre \& Spottiswoode.

CHANDLER, T. 1989. Four thousand years of urban growth: an historical census. Lewiston (NY): St David's.

CHANDL.IR, T. \& G. FOX. 1974. 3000 years of urban growth. New York (NY): Academic

Comune di Roma UfFicio di Statistica e Censimento. 1960. Roma: popolazione e territorio dal 1860 al 1960 con la distribuzione territoriale dei risultati dei censimenti. Rome. 
GrowN, P.L. 1991. Evaluating the construction sequence and population of Pot Creek Pueblo, northern New Mexico, American Antiquity 56(2): 291-314.

CULBERT, T.P. \& D.S. RICE (ed.). 1990. Precolumbian population history in the Maya Lowlands. Albuquerque (NM): University of New Mexico Press.

Detla Corte, M. 1965. Gase ed abitanti di Pompei. 3rd edition. Naples: Casa Editrice Fausto Fiorentino.

DE Vos, A. \& M. DE VOS. 1982. Pompei Ercolano Stabia. Rome: Giuseppi Laterza.

DE VRIES, J. 1984. European urbanization 1500-1800. Cambridge (MA): Harvard University Press.

Esc.HEвACH, H. 1970. Die Stadtbauliche Entwicklung des Antiken Pompeji. Heidelberg: F.H. Kerle Verlag. Mitteilungen des Deutschen Archäologischen Instituts Römische Abteilungen Siebzehntes Erganzungsheft.

1981. Pompei: pianta scavi. Naples: Editore Generoso Procaccini.

EvaNS, S.T. 1993. Aztec household organization and village administration, in R.S. Santley \& K. Hirth (ed.), Prehispanio domestic units in western Mesoamerica: 173-89. Boca Raton (FL): CRC.

FinLAY, R. 1981. Population and metropolis: the demography of London 1580-1650. New York (NY): Cambridge Uníversity Press.

FINLEY, M.I. 1985. Ancient history: evidence and models, London: Chatto \& Windus.

FRANK, T. 1924. Roman census statistics from 225 to $28 \mathrm{BC}$, Clussical Philology 19: 329-41.

FRANKFORT, H. 1950. Town planning in ancient Mesopotamia, Town Planning Review 21(1): 98-115.

GARNSEY, P. \& R. SALLER. 1987. The Roman empire: economy, society and culture. Berkeley (CA): University of California Press.

HAVILAND, W.A. 1972. Family size, prehistoric population estimates, and the ancient Maya, American Antiquity 37: $135-9$.

HEALEN, D.M. 1977. Architectural implications of daily life in ancient Tollan, Hidalgo, Mexico, World Archaeology 9(2): 140-56:

HoDGES R. \& D. WhiteHouse. 1983. Mohammed, Charlemagne and the origins of Europe: archaeology and the Pirenne Hypothesis. London: Duckworth.

Hомо, L. 1951. Rome impériale et l'urbanisme dans l'antiquité. Paris: Éditions Albin Michel.

HONG KONG CENSUS \& STATISTICS DEPARTMENT. 1971. Iong Kong population and housing census 1971 main report. Hong Kong.

HOPKINS, K. 1978. Conquerors and slaves: sociological studies in Roman history 1. New York (NY): Cambridge University Press.

JASHEMSKI, W. 1979. The gardens of Pompeii. New Rochelle (NY): Caratzas.

JONGMAN, W. 1988. The economy and society of Pompeii. Amsterdam: J.C. Gieben

KARDULIAS, N.P. 1992. Estimating population at ancient military sites: the use of historical and contemporary analogy, American Antiquity 57(2): 276-87.

LAURENCE, R. 1994. Roman Pompeii: space and society. New York (NY): Routledge.

1995. The organization of space in Pompeii, in T. Cornell \& K. Lomas (ed.), Urban society in Roman Italy: 63-78. New York (NY): St Martin's.

Lipsius, J. 1605 Admiranda sive de magnitudine Romana. 3rd edition. Antwerp.

Lo CASCIO, E. 1994. The size of the Roman population: Beloch and the meaning of the Augustan census figures, Journal of Roman Studies 84: 23-40.

LOT, F. 1945-1950. Recherches sur la population et Ia superficie des citès remontants à la période Gallo-Romaine. Paris: Libraire Ancienue Honoré Champion.

MCKAY, A.G. 1988. Houses; in M. Grant \& R. Kitzinger (ed.), Civilization of the ancient Mediterranean: Greece and Rome 3: 1373-83. New York (NY): Scribner's.
MAIER, F.G. 1954. Römische Bevölkerungsgeschichte und Inschriftenstatistik, Historia 2(3): 318-51.

MEIGGS, R. 1973. Roman Ostia. 2nd edition. New York (NY): Oxford University Press.

Mrtion, R. 1981. Teatihuacan: city, state, and civilization, in Sabloff (ed.): 198-243.

Ministère DU COMMERCE SERVICE DE LA STATISTIOUE GÉNÉRAle. 1883. Résultats statistique de denombrement de 1881, France et Algérie. Paris: Imprimerie Nationale.

MTISTERO DI AGRICOLTURA, INDUSTRIA E COMMERCIO, DireZione Della STATISTICA. 1883. Censimento della Popolazione del Regno d'llalia al 31 Dicembre 1881 1, Part 1. Popolazione dei communi e mandamenti. Rome: Tipografia Bodoniana.

NibBy, A. 1829. Viaggio antiquario ad Ostia. Rome: Sacieta Tipografia.

Nicolex', C. 1987 La Table d'Héraclée et les origines du cadastre Romain, in LU'Us: espace urbain et histoire (ii ${ }^{\mathrm{er}}$ siècle av. JC-iiir siècle op. JC): 1-25. Rome: École Française de Rome. Collection 98.

NICOLET, C. 1991. Space, geography, and politics in the early Roman Empire. Ann Arbor (MI); University of Michigan Press.

PACKER, J.E. 1971. The Insulae of Imperial Ostia. Rome: American Academy. Memoir 31

PALMER, R.E.A. 1980 Customs on market goods imported into the city of Rome, Memoirs of the American Academy in Rome 36: 217-50.

PAOLI, U.G. 1963[1940] Rome: its people, life and customs. New York (NY): Longman.

PARKIN, T.G. 1992. Roman demography. Baltimore (MD): Johns Hopkins University Press.

1994. Review of Rawson et al, Journal of Roman Shadies 84: $178-85$.

PAvOLINI, C. 1988. Ostia. Rome: Giuseppi Laterza.

PIRCFLL, N. 1987a. Tomb and suburb, in H. von Hesberg \& P. Zanker, Römische Gräbersstassen: Selbstdarstellung-Status-Standard: 25-41. Munich: Verlag Bayerischen Akademie Der Wissenchaften. Abhandlungen Neue Folge, Heft 96.

1987b. Town and country and country in town, in W.F. Jashemski (ed.), Ancient Roman villa gardens: 187-203. Washington (DC): Dumbarton Oaks Research Library and Collection.

Rawson, B. 1986. The Roman family, in B. Rawson (ed.), The family in ancient Rome: new perspectives: $1-57$. Ithaca (NY): Cornell University Press.

1991a. Introduction, in Rawson 1991b: 1-30.

1991b. Marriage, divorce and children in ancient Rome: New York (NY): Oxford University Press.

RICHARDSON, L., JR. 1988. Pompeii: an architectural history. Baltimore (MD): Johns Hopkins University Press.

RoBINSON, O.R. 1992. Ancient Rome: city planning and administrution. New York (NY): Routledge.

RoDRIGUEZ-ALMEIDA, E. 1981. Forma Urbis Marmorea: aggiornamento 1980. Rome: Edizioni Quasar.

RUSSELI, J.C. 1958. Late ancient and medieval populations, Transactions of the Amterican Philosophical Society 48[3]: $1-101$.

1977. The population and mortality at Pompeii, International Committee on Urgent Anthropological and Ethnological Research Bulletin 19: 107-14.

SALI.ER, R.P. 1984. Familia, domus, and the Roman conception of the family, Phoenix 38: 336-55.

SABLOFF, J.A. (ED.). 1981. Supplement to the Handbook of Middle American Indians, 1: Archaeology. Austin (TX): University of Texas Press.

SALLER, R.P. \& B.D. SHAW, 1984. Tombstones and Roman family relations in the principate: civilians, soldiers and slaves, Journal of Roman Studies 74: 124-56.

SANDERS, W.T., J.R. PARSONS \& R.S. SANTLEY. 1979. The Basin of Mexico: ecological process in the evolution of a civilization. New York (NY): Academic. 
SCHINZ, A. 1989. Gities in China. Berlin: Gebrüder Bornträger. SCOBIE, A. 1986. Slums, sanitation, and mortality in the Roman world, Klia 68(2): 399-433.

SHAW, B.D. 1984. Latin funerary epigraphy and family life in the later Roman Empire, Historia 33[4]: 457-97.

StAMBAUGH, J.E. 1988. The ancient Roman city. Baltimore (MD): Johns Hopkins University Press.

Storey, G. 1992. Preindustrial urban demography: the ancient Roman evidence. Ph.D dissertation, Pennsylvania State University, State College (PA).

STOREY, R. 1992. Life and death in the ancient city of Teotihuacan: a modern paleodemographic synthesis. Tuscaloosa (AL): University of Alabama Press.

Strocka, V.M. 1984. Häuser in Pompeji 1: Casa del Principe di Napoli. Tübingen; Verlag Ernst Wasmuth.

UNITED NATIONS. 1980. Compendium of social statistics: 1977. New York (NY): United Nations Publishing Service.

UnITED Nations POPULATION FUnd. 1988. Cilies: slatistical, administrative and graphical information on the major urban areas of the world. Barcelona: Instituts d'Estudis Metropolitans de Barcelona.

VAN DER POEL, H.B. et al. 1983. Corpus topographicum pompeianum: toponymy. Austin (TX): University of Texas Press.
WALLACE-HADRILL, A. 1991. Houses and households: sampling Pompeii and Herculaneum, in Rawson 1991b; 191-227. 1994. Houses and society in Pompeii and Herculaneum. Princeton (NJ): Princeton University Press.

WAROEN, P.D. \& R.S. BAgNall. 1988. The forty thousand citizens of Ephesus, Classical Philology 83: 220-23.

WARD-PERKINS, J.B. 1974. Cities of ancient Greece and Italy; plunning in classical antiquity. New York (NY): George Braziller.

WEAVER, P.R.C. 1972. Familia Caesaris: a social study of the Emperor's freedmen and slaves. New York (NY]: Cambridge University Press.

WEBSTER, D.L. \& A. FRETER. 1990. Settlement history and the Classic 'collapse' at Copán: a refined chronological perspective, Latin American Antiquity 1(1): 66-85.

WeISs, K.M. 1973. Demographic models for anthropology. Washington (DG): Society for American Archaeology. Memoirs 27.

WESTERMANN, W.L. 1955. The sIave systems of Greek and Romun antiquity. Philadelphia (PA): American Philosophical Society. Memoirs 40.

WiEDEMANN, T.J. 1981. Greek and Roman slavery. Baltimore (MD): Johns Hopkins University Press.

WISEMAN, T.P. 1969. The census in the first century BC, Journal of Roman Studies: 59: 59-75. 